\title{
THE ATTITUDES OF UNIVERSITY STUDENTS WHO RECEIVED ONLINE EDUCATION DURING THE PANDEMIC TOWARDS COVID-19 VACCINES
}

\section{POSTAWY STUDENTÓW UCZELNI WYŻSZYCH KORZYSTAJĄCYCH Z EDUKACJI ONLINE W OKRESIE PANDEMII WOBEC SZCZEPIONKI PRZECIW COVID-19}

\author{
Nilhan Töyer Şahin ${ }^{1(A, B, C, D, E, F, G)}$, Tuğba Öz $\mathbf{z}^{1(A, B, C, D, E, F, G)}$, Ömer Serdar Sonceley ${ }^{1(A, B, C, D, E, F, G)}$ \\ ${ }^{1}$ Vocational School of Health Services, Istanbul Esenyurt University, Istanbul, Turkey
}

Authors' contribution Wkład autorów: A. Study design/planning zaplanowanie badań B. Data collection/entry zebranie danych C. Data analysis/statistics dane - analiza i statystyki D. Data interpretation interpretacja danych E. Preparation of manuscript przygotowanie artykułu F. Literature analysis/search wyszukiwanie i analiza literatury G. Funds collection zebranie funduszy

Tables: 5

Figures: 1

References: 16

Submitted: 2021 Jul 27

Accepted: 2021 Sep 9

\section{Summary}

Background. The study was conducted to determine the attitudes of university students who received online education during the pandemic towards COVID-19 vaccines.

Material and methods. This descriptive and correlational type study was conducted between April and June 2021. There were approximately 2,500 students studying at a private university in Istanbul during the 2020-2021 academic year, and the sample size was 222 . The data collection tools used included the student information form and the Perception and Attitude Scale Related with COVID-19 pandemic. The data were analyzed using number, percentage, mean and Student's t-test, Mann Whitney U-test and one way ANOVA.

Results. The mean positive attitude score towards COVID-19 vaccines was 3.37, and the negative attitude score towards COVID-19 vaccines was 3.24. It was concluded that students' attitudes towards the vaccine were undecided.

Conclusions. Factors such as age, gender, residential area, family type, presence of chronic disease or being diagnosed with COVID-19 do not make a significant difference in the attitude of students towards COVID-19 vaccines. Marital status was the only significant factor that made a difference in attitude towards COVID-19 vaccines.

Keywords: online education, COVID-19 vaccine, pandemic, COVID-19, students

\section{Streszczenie}

Wprowadzenie. Celem badania było określenie postaw studentów uczelni wyższych, którzy w okresie pandemii korzystali z edukacji online, wobec szczepionki przeciw COVID-19.

Materiał i metody. Badanie o charakterze opisowym i korelacyjnym przeprowadzono w okresie od kwietnia do czerwca 2021 roku. Na prywatnym uniwersytecie w Stambule w roku akademickim 2020-2021 studiowało ok. 2,500 studentów. Grupa badana objęła 222 studentów. Jako narzędzie do zbierania danych wykorzystano formularz informacyjny dla studentów oraz Skalę Postrzegania i Postaw związanych z pandemia COVID-19. Uzyskane dane analizowano za pomocą liczby, odsetka, średniej oraz testu t-studenta, testu U Manna Whitneya, a także jednoczynnikowej analizy wariancji.

Wyniki. Na podstawie średniej oceny studentów ustalono, że poziom pozytywnej postawy wobec szczepionki przeciw COVID-19 wynosi 3,37, a poziom negatywnej postawy wobec szczepionki przeciw COVID-19 wynosi 3,24. Stwierdzono, że postawa studentów wobec szczepionki jest niejednoznaczna.

Wnioski. Stwierdzono, że czynniki takie jak wiek, płeć, miejsce zamieszkania, typ rodziny, choroby przewlekłe lub zdiagnozowany COVID-19 nie maja istotnego wpływu na postawe wobec szczepionki. Tylko stan cywilny miał istotny wpływ na postawę wobec szczepionki przeciw COVID-19.

Słowa kluczowe: edukacja online, szczepionka przeciw COVID-19, pandemia, COVID-19, studenci 


\section{Introduction}

COVID-19 has become a global problem that started in Wuhan, China in 2019. This epidemic has caused many changes to the global way of life. COVID-19, which started in a small area, has reached global status in a short time [1]. The World Health Organization (WHO) defined COVID-19 as a pandemic on March 11, 2020. With the announcement of the pandemic, WHO warned that interpersonal interaction should be limited and individuals should pay more attention to hygiene [2]. In order to prevent the wide spread of COVID-19, the most important measures taken at the national and international level have been the isolation of people and implementation of curfews.

Transportation, economy, food, entertainment, sports, shopping and health sectors are included in the measures taken. Like many other sectors, the education sector has also been affected. The first measure taken for the education sector was to switch to the online process. With numerous studies carried out, more information has been obtained about the transmission routes of COVID-19, its effects and consequences. Based on the data obtained, returning to the old model of education was not an option so studies looking at distance education during COVID-19 increased. With the first COVID-19 case in Turkey in March 2020, universities switched to online education and continue to utilize this model [3].

While prevention measures continue globally, research looking at immunization has become a priority. Community immunity is a way of immunizing against a contagious disease either through vaccination or through previous infection. Vaccines play an important role in the prevention and immunization of infectious diseases. Vaccines both control the epidemics of infectious diseases and can prevent the emergence of diseases [3].

Vaccination not only protects individuals against infection but also can prevent the spread of the epidemic. Therefore, if a sufficient number of the population is vaccinated, community immunity increases [4]. For the formation of herd immunity, the WHO supports immunization with vaccination, not the formation of antibodies by allowing the spread of the disease. If the spread of the disease and the immunization method were supported, there would be unavoidable cases and deaths. Although the required herd immunity differs according to each disease, this rate is not yet known for COVID-19. Although it was estimated to be around 60-70\% at the beginning of the epidemic, it has been reported that higher herd immunity may be needed in recent studies [5].

To achieve herd immunity against COVID-19, a proportion of the population must be vaccinated which varies depending on priority groups, vaccination, population and other factors [6]. With the use of vaccines, there is a mix of positive attitudes along with concerns about the vaccine. Inaccurate and incomplete information about vaccines and different beliefs can cause vaccine hesitancy. Vaccine hesitancy refers to "delayed or refused acceptance of vaccines despite the availability of vaccine services" [7]. The WHO also sees vaccine hesitancy among the ten global health threats. It can be formed around the legal, medical and ethical issues related to vaccines [8]. Apart from the reasons for vaccine hesitation, the debates relating to personal rights are also seen as an obstacle to immunization. The opinions that community immunity is more effective with an understanding of the transmission, that vaccine manufacturers have financial concerns, and that immunity can be obtained by consuming natural foods and herbs may cause hesitations about the vaccine [7]. It is evident that vaccine hesitancy is due to lack of knowledge and false beliefs. In order to halt this from impacting community immunity, healthcare professionals should be supported with accurate and reliable information about vaccines [9].

Considering vaccine hesitancy does not encompass the whole of society and instead is limited to certain groups, it is important to understand which groups are hesitant about vaccination, the events that increase the hesitation, the reason for their concerns, and the geographical location, political environment or socio-cultural characteristics of the individuals who are hesitant [10]. Based on this research, this study aimed to determine the attitudes of university students who received online education during the pandemic period towards the COVID-19 vaccine.

\section{Material and methods}

\section{Type of research}

This is a descriptive study using qualitative data to capture the attitudes of university students towards COVID-19 vaccination.

\section{Population and sample of the research}

The study population consisted of first and second year students studying at the Vocational School of Health Services, Istanbul Esenyurt University, Turkey. Students were invited via the snowball method. The research 
was completed between 15 May and 15 June 2021 with 222 students who agreed to participate in the study by an online survey method.

\section{Data collection tools}

Descriptive information form was a questionnaire created by the researchers and includes demographic information such as age, gender, marital status, family type, working status during the pandemic period, use of public transport, and status of COVID-19.

\section{Scale of Attitudes Towards COVID-19 Vaccines}

The Attitudes Towards COVID-19 Vaccine Scale has nine items and two sub-dimensions (positive and negative attitudes). The statements in the scale are evaluated as "strongly disagree (1)", "disagree (2)", "undecided (3)", "agree (4)", and "strongly agree (5)". Items in the negative attitude sub-dimensions are scored negatively. A value between 1-5 is obtained by dividing the total score obtained by summing the item scores in the scale sub-dimension by the number of items in that sub-dimension. High scores obtained from the positive attitude sub-dimension indicate that the attitude towards the vaccine is positive. This is calculated after the items in the negative attitude sub-dimension are reversed, and the high scores in this sub-dimension indicate that the negative attitude towards the vaccine is less. Reverse items of the scale were coded as shown $1 \rightarrow 5 ; 2 \rightarrow 4 ; 3 \rightarrow 3$; $4 \rightarrow 2 ; 5 \rightarrow 1$.

\section{Analysis of data}

The data obtained from the research were analyzed using the Statistical Package for the Social Version 22.0 (SPSS) package program. The suitability of the data to the normal distribution was tested, the Independent Sample t-test was used in the analysis of continuous variables with normal distribution, and the Mann Whitney U-test was used in the analysis of continuous variables that did not show normal distribution. A chi-square test was used in the analysis of categorical variables. Results were expressed as mean, \pm standard deviation, $\mathrm{n}$, and percent.

\section{Ethical aspect of research}

Permission to perform the research was obtained from the Istanbul Esenyurt University Ethics Committee at the meeting numbered 2021/05-12 dated $15^{\text {th }}$ April 2021. The research was conducted in accordance with the Principles of the Declaration of Helsinki.

\section{Results}

Of the participants, $59.5 \%$ were female and $40.5 \%$ male. When the distribution by age groups was examined, the proportion of people aged $18-25$ was $94.1 \%, 26-34$ was $5 \%$, and people aged 35 and over was $0.9 \%$ (Figure 1). When the distribution according to the education year was examined, there were $77 \%$ of first-year students and $23 \%$ of second-year students. The proportion of those living in the metropolitan city was $53.6 \%$, those living in the province was $19.8 \%$, those living in the district was $20.7 \%$, and those living in the village was $5.9 \%$. The proportion of those married was $4.1 \%$ and those who were single was $95.9 \%$. When the distribution by family type was examined, the proportion of those living alone was $7.2 \%$, those with a nuclear family was $78.4 \%$, and those with an extended family was $14.4 \%$ (Table 1). 


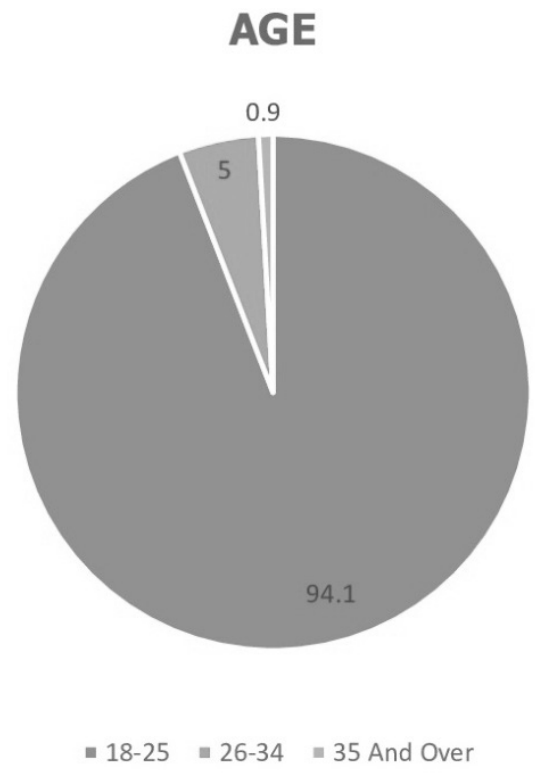

Figure 1. Age distribution of the participants

Table 1. Demographic characteristics of the participants

\begin{tabular}{|c|c|c|c|}
\hline Demographic features & Options & $\mathbf{n}$ & $\mathbf{\%}$ \\
\hline \multirow{2}{*}{ Gender } & Female & 132 & 59.5 \\
\cline { 2 - 4 } & Male & 90 & 40.5 \\
\hline \multirow{3}{*}{ Study year } & $18-25$ & 209 & 94.1 \\
\cline { 2 - 4 } & $26-34$ & 11 & 5.0 \\
\cline { 2 - 4 } & 35 and over & 2 & 0.9 \\
\hline \multirow{3}{*}{\begin{tabular}{c} 
Place of residence \\
\cline { 2 - 4 }
\end{tabular}} & $1^{\text {st }}$ year & 171 & 23.0 \\
\cline { 2 - 4 } & Metropolitan & 51 & 53.6 \\
\cline { 2 - 4 } & Province & 119 & 19.8 \\
\hline \multirow{2}{*}{ Marital status } & District & 44 & 20.7 \\
\cline { 2 - 4 } & Rural & 46 & 5.9 \\
\cline { 2 - 4 } & Married & 13 & 4.1 \\
\hline \multirow{2}{*}{ Family type } & Single & 9 & 95.9 \\
\hline & Single & 213 & 7.2 \\
\hline
\end{tabular}

The distribution according to the type of work shows the proportion of participants that work from home online was $49.1 \%$, those who work face-to-face was $19.8 \%$, and those who work with both was $31.1 \%$. Of the participants, $64 \%$ use public transportation, $7.7 \%$ have chronic diseases, and $56.3 \%$ with chronic diseases have asthma. Among the participants, the proportion of those who have had a coronavirus test was $39.2 \%$, and the proportion of those who were diagnosed with COVID-19 was 30.1\%. The proportion of those who had relatives with COVID-19 was $65.8 \%$ (Table 2). 
Table 2. Descriptive characteristics of the participants

\begin{tabular}{|c|c|c|c|}
\hline Descriptive features & Options & n & $\%$ \\
\hline \multirow{3}{*}{ Method of working } & Online, from home & 109 & 49.1 \\
\hline & Face to face-active & 44 & 19.8 \\
\hline & Mixed & 69 & 31.1 \\
\hline \multirow{2}{*}{ Public transport usage status } & Yes & 142 & 64.0 \\
\hline & No & 80 & 36.0 \\
\hline \multirow{2}{*}{ Chronic illness } & Yes & 17 & 7.7 \\
\hline & No & 205 & 92.3 \\
\hline \multirow{2}{*}{ Existing chronic conditions } & Asthma & 9 & 56.3 \\
\hline & Other & 7 & 43.8 \\
\hline \multirow{2}{*}{ Coronavirus test status } & Yes & 87 & 39.2 \\
\hline & No & 135 & 60.8 \\
\hline \multirow{2}{*}{$\begin{array}{l}\text { Status of being diagnosed with } \\
\text { COVID-19 }\end{array}$} & Yes & 41 & 30.1 \\
\hline & No & 95 & 69.9 \\
\hline \multirow{2}{*}{$\begin{array}{l}\text { COVID-19 detection status in } \\
\text { relatives }\end{array}$} & Yes & 146 & 65.8 \\
\hline & No & 76 & 34.2 \\
\hline
\end{tabular}

The average scores of the attitudes towards the COVID-19 vaccine, according to demographic information, and the difference between these were examined using t-tests and one-way analysis of variance in independent groups (Table 3). According to the results, the level of negative attitude differs significantly according to marital status $(p<0.05)$ while positive and negative attitudes do not differ in relation to the demographic factors. The average of those who were married was significantly higher than those who were single and the negative attitude level of those who were single was significantly higher than the married ones.

Table 3. Change of attitude scale towards COVID-19 vaccine according to demographic information

\begin{tabular}{|c|c|c|c|c|c|c|c|c|c|}
\hline & & \multicolumn{4}{|c|}{ Positive } & \multicolumn{4}{|c|}{ Negative } \\
\hline & & $\mathbf{n}$ & Mean & Std. & p & $\mathbf{n}$ & Mean & Std. & $\mathbf{p}$ \\
\hline \multirow{2}{*}{ Gender } & Female & 132 & 3.27 & 1.02 & \multirow{2}{*}{0.057} & 132 & 3.17 & 0.71 & \multirow{2}{*}{0.109} \\
\hline & Male & 90 & 3.53 & 1.01 & & 90 & 3.33 & 0.78 & \\
\hline \multirow{3}{*}{ Age } & $18-25$ & 209 & 3.37 & 1.01 & \multirow{3}{*}{0.778} & 209 & 3.22 & 0.73 & \multirow{3}{*}{0.375} \\
\hline & $26-34$ & 11 & 3.52 & 1.37 & & 11 & 3.53 & 0.95 & \\
\hline & 35 and over & 2 & 3.00 & 0.00 & & 2 & 3.00 & 0.28 & \\
\hline \multirow{2}{*}{ Study year } & $1^{\text {st }}$ year & 171 & 3.40 & 0.98 & \multirow{2}{*}{0.448} & 171 & 3.25 & 0.73 & \multirow{2}{*}{0.649} \\
\hline & $2^{\text {nd }}$ year & 51 & 3.27 & 1.16 & & 51 & 3.18 & 0.77 & \\
\hline \multirow{4}{*}{$\begin{array}{l}\text { Place of } \\
\text { residence }\end{array}$} & Metropolitan & 119 & 3.44 & 1.12 & \multirow{4}{*}{0.448} & 119 & 3.29 & 0.79 & \multirow{4}{*}{0.649} \\
\hline & Province & 44 & 3.16 & 0.88 & & 44 & 3.13 & 0.70 & \\
\hline & District & 46 & 3.42 & 0.86 & & 46 & 3.23 & 0.64 & \\
\hline & Rural & 13 & 3.29 & 1.05 & & 13 & 3.15 & 0.75 & \\
\hline \multirow{2}{*}{ Marital status } & Married & 9 & 3.25 & 1.61 & \multirow{2}{*}{0.714} & 9 & 4.02 & 0.88 & \multirow{2}{*}{$0.001^{*}$} \\
\hline & Single & 213 & 3.38 & 1.00 & & 213 & 3.20 & 0.72 & \\
\hline \multirow{3}{*}{ Family type } & Single & 16 & 3.30 & 1.08 & \multirow{3}{*}{0.708} & 16 & 3.05 & 0.76 & \multirow{3}{*}{0.528} \\
\hline & Nuclear family & 174 & 3.40 & 1.03 & & 174 & 3.26 & 0.72 & \\
\hline & $\begin{array}{c}\text { Extended } \\
\text { family }\end{array}$ & 32 & 3.25 & 0.98 & & 32 & 3.20 & 0.83 & \\
\hline \multirow{3}{*}{$\begin{array}{l}\text { Method of } \\
\text { working }\end{array}$} & $\begin{array}{c}\text { Online, from } \\
\text { home }\end{array}$ & 109 & 3.37 & 1.00 & \multirow{3}{*}{0.479} & 109 & 3.30 & 0.70 & \multirow{3}{*}{0.375} \\
\hline & $\begin{array}{l}\text { Face to face- } \\
\text { active }\end{array}$ & 44 & 3.23 & 1.12 & & 44 & 3.12 & 0.89 & \\
\hline & Mixed & 69 & 3.47 & 0.99 & & 69 & 3.21 & 0.69 & \\
\hline \multirow{2}{*}{$\begin{array}{c}\text { Public } \\
\text { transport } \\
\text { usage status }\end{array}$} & Yes & 142 & 3.40 & 1.05 & \multirow{2}{*}{0.651} & 142 & 3.28 & 0.76 & \multirow{2}{*}{0.294} \\
\hline & No & 80 & 3.33 & 0.98 & & 80 & 3.17 & 0.71 & \\
\hline \multirow{2}{*}{ Chronic illness } & Yes & 17 & 3.32 & 0.96 & \multirow{2}{*}{0.837} & 17 & 3.18 & 0.55 & \multirow{2}{*}{0.726} \\
\hline & No & 205 & 3.38 & 1.03 & & 205 & 3.24 & 0.75 & \\
\hline
\end{tabular}




\begin{tabular}{|c|c|c|c|c|c|c|c|c|c|}
\hline \multirow{2}{*}{$\begin{array}{c}\text { Existing } \\
\text { chronic } \\
\text { conditions } \\
\end{array}$} & Asthma & 9 & 3.17 & 1.15 & \multirow{2}{*}{0.609} & 9 & 3.09 & 0.72 & \multirow{2}{*}{0.446} \\
\hline & other & 7 & 3.43 & 0.73 & & 7 & 3.31 & 0.25 & \\
\hline \multirow{2}{*}{$\begin{array}{l}\text { Coronavirus } \\
\text { test status }\end{array}$} & Yes & 87 & 3.41 & 1.01 & \multirow{2}{*}{0.632} & 87 & 3.23 & 0.74 & \multirow{2}{*}{0.909} \\
\hline & No & 135 & 3.35 & 1.03 & & 135 & 3.24 & 0.74 & \\
\hline \multirow{2}{*}{$\begin{array}{l}\text { Status of being } \\
\text { diagnosed with } \\
\text { COVID-19 } \\
\end{array}$} & Yes & 41 & 3.39 & 1.07 & \multirow[b]{2}{*}{0.82} & 41 & 3.24 & 0.81 & \multirow[b]{2}{*}{0.990} \\
\hline & No & 95 & 3.43 & 1.01 & & 95 & 3.24 & 0.75 & \\
\hline \multirow{2}{*}{$\begin{array}{l}\text { COVID-19 } \\
\text { detection } \\
\text { status in } \\
\text { relatives } \\
\end{array}$} & Yes & 146 & 3.30 & 1.04 & \multirow[b]{2}{*}{0.150} & 146 & 3.24 & 0.73 & \multirow[b]{2}{*}{0.990} \\
\hline & No & 76 & 3.51 & 0.98 & & 76 & 3.24 & 0.76 & \\
\hline
\end{tabular}

The mean and standard deviation values of the scale sub-dimensions are provided in Table 4. For the subdimensions ranging from 1-5, the average for the positive attitude sub-dimension was 3.37 and the average for the negative attitude was 3.24 .

Table 4. Descriptive statistics of the scale sub-dimensions

\begin{tabular}{|c|c|c|c|c|c|}
\hline & n & Min. & Max. & Mean & Std. \\
\hline Positive & 222 & 1.0 & 5.0 & 3.37 & 1.02 \\
\hline Negative & 222 & 1.0 & 5.0 & 3.24 & 0.74 \\
\hline
\end{tabular}

Of the participants, 7.7\% gave the answer "I strongly disagree" with the statement "I would like to have this vaccine in my family" and the proportion of those who gave the answer "I disagree" was 6.3\%, whilst 35.5\% were "I am undecided". The proportion of those who gave the answer "I agree" with the same question was $29.7 \%$, while the proportion of those who answered "I strongly agree" was $20.7 \%$. The proportion of the participants who answered "I strongly disagree" with the statement "I would like to be vaccinated at the first opportunity" was $9 \%$, while $6.8 \%$ answered "I disagree" was 6.8\%, and those that stated "I am undecided" had the highest proportion. The proportion of those who answered "I agree" to the same question was 27.9\%, and those who answered "I strongly agree" was $18 \%$.

The proportion of participants who gave the answer "I strongly disagree" with the statement "I think everyone should get the vaccine" was 5.9\%, those who gave the answer "I disagree" was $11.3 \%$, and those who answered "I am undecided" was the highest at 34.7\%. The proportion of those who gave the answer "I agree" with the same statement was $28.4 \%$, and those who gave the answer "I agree" was $19.8 \%$.

The proportion of participants who answered "I strongly disagree" with the statement "I trust the explanations about the vaccine" was $9.9 \%$, those who gave the answer "I disagree" was $11.3 \%$, and those who answered "I am undecided" was $43.2 \%$. While the proportion of those who gave the answer "I agree" to the same statement was $24.8 \%$ and those who gave the answer "I strongly agree" was $10.8 \%$. The proportion of participants who answered "I strongly disagree" with the statement "The vaccine may cause the disease to be transmitted" was 8.6\%, those who answered "I disagree" 30.6\%, and those who answered "I am undecided" was the highest at $46.8 \%$. The proportion of those who answered "I agree" with the same statement was $10.8 \%$, while those who answered "I strongly agree" was 3.2\%. The proportion of those who answered "I strongly disagree" with the statement "I do not think that the vaccine has a protective effect" was 9.9\%, those who answered "I disagree" was $29.7 \%$, and those who answered "I am undecided" was $42.3 \%$. The proportion of those who answered "I agree" was $13.1 \%$ and those answered "I agree" was 5\%.

In this study, the proportion of those who answered "I strongly disagree" with the statement "the vaccine is dangerous" was $13.1 \%$, the proportion of those who answered "I disagree" was 33.8\%, and those who answered "I am undecided" was 45\%. The proportion of those who answered "I agree" was 5.9\%, while those who answered "I strongly agree" was $2.3 \%$. The proportion of those who answered "I strongly disagree" with the statement "I think the effectiveness of the vaccine has not been sufficiently tested" was 8.6\%, those who answered "I disagree" was 25.2\%, and those who gave the answer "I am undecided" was 39.6\%. The proportion of those who answered "I agree" was 18.5\%, while those who answered "I strongly agree" was 8.1\%. The proportion of those who answered "I strongly disagree" with the statement "I think I can overcome the epidemic without vaccination" was $14.4 \%$, those who answered "I disagree" was $19.4 \%$, and those who answered "I am undecided" was $32.4 \%$. The proportion of those who gave the answer of "I agree" was 23.4\%, while those who gave the answer "I agree" was 10.4\% (Table 5). 
Table 5. Percentage distribution of attitude scale towards COVID-19 vaccine

\begin{tabular}{|c|c|c|c|c|c|}
\hline $\begin{array}{c}\text { Attitude scale questions for } \\
\text { the COVID-19 vaccine }\end{array}$ & $\begin{array}{c}\text { I strongly } \\
\text { disagree }\end{array}$ & I do not agree & I'm undecided & I agree & $\begin{array}{c}\text { I absolutely } \\
\text { agree }\end{array}$ \\
\hline $\begin{array}{c}\text { I would like my family to } \\
\text { have this vaccine }\end{array}$ & 7.7 & 6.3 & 35.6 & 29.7 & 20.7 \\
\hline $\begin{array}{c}\text { I would like to be vaccinated } \\
\text { as soon as possible }\end{array}$ & 9 & 6.8 & 38.3 & 27.9 & 18 \\
\hline $\begin{array}{c}\text { I think everyone should get } \\
\text { vaccinated }\end{array}$ & 5.9 & 11.3 & 44.7 & 24.4 & 10.8 \\
\hline $\begin{array}{c}\text { I trust the explanations } \\
\text { about the vaccine }\end{array}$ & 9.9 & 11.3 & 46.8 & 10.8 & 3.2 \\
\hline $\begin{array}{c}\text { Vaccination can cause } \\
\text { disease transmission }\end{array}$ & 8.6 & 3.9 & 42.3 & 13.1 & 5 \\
\hline $\begin{array}{c}\text { I think the vaccine has no } \\
\text { protective effect }\end{array}$ & 13.1 & 33.8 & 45 & 5.9 & 2.3 \\
\hline Vaccination is dangerous & 8.6 & 25.2 & 39.6 & 18.5 & 8.1 \\
\hline $\begin{array}{c}\text { I think the efficacy of } \\
\text { the vaccine has not been } \\
\text { sufficiently tested }\end{array}$ & 14.4 & 19.4 & 32.4 & 23.4 & 10.4 \\
\hline $\begin{array}{c}\text { I think I can survive the } \\
\text { epidemic without a vaccine }\end{array}$ & & 29.7 & & \\
\hline
\end{tabular}

\section{Discussion}

The WHO supports vaccination for the formation of herd immunity. To achieve herd immunity against COVID-19, a proportion of the population must be vaccinated [6]. The WHO also rate vaccine hesitancy among the ten global health threats [7]. Inaccurate and incomplete information about vaccines and different beliefs create hesitancy or opposition to vaccines [8].

The number of studies similar to this study was limited in the literature. However in this study, the highest average of university students' answers to vaccine-related scale items was "undecided".

In the study by Akarsu et al. (2020), of the 759 participants, the most common reasons for those that would not be vaccinated were "fear of the side effects of the vaccine", "not thinking that a new vaccine would be reliable" and "COVID-19 infection is a biological weapon and the vaccine serves those who produce this virus". It was concluded that "I do not think that it will happen" [11].

There has been general hesitation against vaccines produced throughout human history. The hesitation against the COVID-19 vaccine and other vaccines shows parallelism. However, in some countries, this is not the case, and it has been determined that the hesitation against the COVID-19 vaccine was higher. Among these countries, Turkey had the highest vaccination hesitation at 44\%. Since people do not agree on vaccination yet, social immunity cannot be provided [12].

According to the results of the "Turkey Report" conducted in 12 provinces across Turkey in April 2021; 20\% of the participants were vaccinated, $53 \%$ were considering getting vaccinated, and $25 \%$ were not getting the COVID-19 vaccine [13]. In the report presented in January, the rate of those who did not plan to be vaccinated was $36 \%$ which was a slight decrease. Participants who do not plan to be vaccinated stated that they hesitated because of the thought of not trusting the current vaccines and not believing in the efficacy of the vaccines.

In another study conducted in April 2021, 61\% of those who had not been vaccinated reported they would be vaccinated. This rate has increased compared to previous data, however, there is still a group of $14 \%$ who refuse to be vaccinated. Of the participants, $14 \%$ stated that they were exposed to anti-vaccine news rather than news supporting the vaccine [14].

In a study conducted in the USA, $45 \%$ of the participants had concerns about the content of vaccines, $50 \%$ thought of getting the vaccine at the first opportunity, $40 \%$ preferred to wait for a while, and $10 \%$ did not think of ever getting vaccinated [15]. They reported that those who were considering vaccinations perceived COVID-19 as more important than other diseases and that vaccination was needed to end epidemic. In addition the participants stated that they trusted the health authorities.

A study from the United Kingdom $(n>30,000)$ reported that $16 \%$ of the participants had a high level of distrust of the COVID-19 vaccine [16]. When the demographic characteristics of those who were insecure were examined, they had low education levels and low income levels. It was determined that the participants in this group had insufficient knowledge about COVID-19 and were less compliant with isolation-hygiene measures. 
The current pandemic brings with it some challenges. The public's trust in the vaccine produced/to be produced can be considered the main reason for the opposition. Especially if the data and evidence about the vaccine are insufficient and the vaccine is new, the level of hesitation increases accordingly. On the other hand, the thoughts of pharmaceutical companies gaining profit from sales and misinformation by anti-vaccine groups may be the reason why society, where the side effects of vaccines are uncertain and natural immunity is preferred, may be prejudiced against the vaccine produced/to be produced. The position of university students, which has a significant number throughout Turkey, is very important in reaching the sufficient level of herd immunity. Therefore, it is thought that the concerns of students who have been studying online for more than a year about vaccination should be determined and resolved.

\section{Conclusions}

The COVID-19 pandemic continues to affect people all over the world. As a result of the study, it was found that university students who received online education during the pandemic process had positive attitudes towards the COVID-19 vaccine. Factors such as age, gender, residential area, family type, presence of chronic disease or being diagnosed with COVID-19 do not make a significant difference in the attitude towards the COVID-19 vaccine. It was concluded that only marital status made a significant difference in attitude towards the COVID-19 vaccine. It has been concluded that since vaccination, which is the most effective method in the fight against the COVID-19 pandemic, is important in terms of applicability, it is also important to raise awareness for university students who receive online education and to switch to face-to-face training.

\section{Disclosures and acknowledgments}

The authors declare no potential conflicts of interest with respect to the research, authorship, and/or publication of this article. This work was funded by the authors.

\section{References:}

1. Şeker M, Özer A, Korkut C. [Anatomy of the global epidemic, the future of human and society]. In: Özer M, Suna E., editors. [COVID-19 outbreak and education]. Ankara: TÜBA; 2020. pp. 175 (in Turkish).

2. www.who.int [Internet]. Geneva: WHO; 2020. WHO Timeline - COVID-19 [cited 2020 Dec 12]. Available from: https://www.who.int/news/item/27-04-2020-who-timeline---COVID-19

3. Özer M. Educational policy actions by the ministry of national education in the times of COVID-19. Kastamonu Education Journal. 2020; 28(3): 1124-1129 https://doi.org/10.24106/kefdergi.722280

4. Çöl M. [Importance of vaccination and opposition to vaccination] [Internet]. Ankara: Ankara University [cited 2021 May 8]. Available from: http://hastane.ankara.edu.tr/2020/03/05/asilamanin-onemi-ve-asikarsitligi (in Turkish).

5. www.who.int [Intenet]. Geneva: WHO; 2020. Coronavirus disease (COVID-19): herd immunity, lockdowns and COVID-19 [cited 2021 May 21]. Available from: https://www.who.int/news-room/q-a-detail/herdimmunity-lockdowns-and-COVID-19

6. Aschwanden C. Five reasons why COVID herd immunity is probably impossible. Nature. 2021; 591: 520-522. https://doi.org/10.1038/d41586-021-00728-2

7. www.who.int [Internet]. Geneva: World Health Organization. Ten threats to global health in 2019 [cited 2021 May 9]. Available from: https://www.who.int/news-room/spotlight/ten-threats-to-global-health-in-2019

8. World Health Organization, SAGE Working Group. Report of the SAGE working group on vaccine hesitancy [Internet]. Geneva: World Health Organization; 2014 [cited 2021 May 9]. Available from: https://www.who. int/immunization/sage/meetings/2014/october/1_Report_WORKING_GROUP_vaccine_hesitancy_final.pdf

9. Larson HJ, Jarrett C, Schulz WS, Chaudhuri M, Zhou Y, Dube E, et al. SAGE Working Group on vaccine hesitancy. Measuring vaccine hesitancy: the development of a survey tool. Vaccine. 2015; 33(34): $4165-4175$. https://doi.org/10.1016/j.vaccine.2015.04.037

10. Karabela SN, Coşkun F, Hoşgör H. Investigation of the relationships between perceived causes of COVID-19, attitudes towards vaccine and level of trust in information sources from the perspective of Infodemic: the case of Turkey. BMC Public Health. 2021; 21: 1195. https://doi.org/10.1186/s12889-021-11262-1.

11. Akarsu B, Canbay Özdemir D, Ayhan Başer D, Aksoy H, Fidancı İ, Cankurtaran M. While studies on COVID-19 vaccine is ongoing, the public's thoughts and attitudes to the future COVID-19 vaccine. The International Journal of Clinical Practice. 2021; 75(4): e13891. https://doi.org/10.1111/ijcp.13891 
12. Feleszko W, Lewulis P, Czarnecki A, Waszkiewicz P. Flattening the curve of COVID-19 vaccine rejection. An international overview. Vaccines. 2021; 9(1): 44. https://doi.org/10.3390/vaccines9010044

13. www.turkiyeraporu.com [Internet]. Istanbul: Istanbul Ekononomi Araştırma; 2021 Apr 30. [Are you considering getting a coronavirus vaccine?] [cited $2021 \mathrm{Aug} 27$ ]. Available from: https://www.turkiyeraporu. com/arastirma/koronavirus-asisi-olmayidusunuyor-musunuz-2-4230/ (in Turkish).

14. www.ipsos.com [Internet]. Istanbul: Ipsos. [The ratio of people who recommended vaccination to their neighbors has increased by 6 points since the beginning of the year] [cited 2021 Aug 27]. Available from: https://www.ipsos.com/tr-tr/yakin-cevresine-asiyaptirmalarini-onerenlerin-orani-yilin-basindan-buyana-6-puan-artti (in Turkish).

15. Salmon DA, Dudley MZ, Brewer J, Kan L, Gerber JE, Budigan H, et al. COVID-19 vaccination attitudes, values and intentions among United States adults prior to emergency use authorization. Vaccine. 2021; 39(19): 2698-2711. https://doi.org/10.1016/j.vaccine.2021.03.034

16. Paul E, Steptoe A, Fancourt D. Attitudes towards vaccines and intention to vaccinate against COVID19: implications for public health communications. Lancet Reg Heal. 2021; 1: 100012.

https://doi.org/10.1016/j.lanepe.2020.100012 